\title{
The Importance of Including Water Temperature Simulations in a 2D Fish Habitat Model for the St. Lawrence River
}

\author{
Valerie Ouellet $^{1,2, * \mathbb{D}}$, André St-Hilaire ${ }^{1} \mathbb{D}$, Yves Secretan $^{1} \mathbb{D}$, Marc Mingelbier $^{3}$, Jean Morin ${ }^{4}$ \\ and Stephen J. Dugdale 5
}

1 INRS-Centre Eau Terre Environnement, 490 de la Couronne, Québec City, QC G1K 9A9, Canada; Andre.St-Hilaire@ete.inrs.ca (A.S.-H.); yves.secretan@ete.inrs.ca (Y.S.)

2 Integrated Statistics Inc., National Oceanic and Atmospheric Administration, Northeast Fisheries Science Center, 17 Godfrey Drive, Orono, ME 04473, USA

3 Direction de L'expertise sur la Faune Aquatique, Ministère des Forêts, de la Faune et des Parcs du Québec, 880 Chemin Sainte-Foy, 2e étage, Québec City, QC G1S 4X4, Canada; Marc.Mingelbier@mffp.gouv.qc.ca

4 Environnement et Changement Climatique Canada, Service Météorologique du Canada-Section Hydrologie, 801-1550 Avenue d'Estimauville, Québec City, QC G1J 0C3, Canada; jean.morin@canada.ca

5 School of Geography, University of Nottingham, Nottingham NG7 2RD, UK;

Stephen.Dugdale@nottingham.ac.uk

* Correspondence: valeria.ouellet@gmail.com

Citation: Ouellet, V.; St-Hilaire, A.; Secretan, Y.; Mingelbier, M.; Morin, J.; Dugdale, S.J. The Importance of Including Water Temperature Simulations in a 2D Fish Habitat Model for the St. Lawrence River Water 2021, 13, 1736. https:// doi.org/10.3390/w13131736

Academic Editor: José Maria Santos

Received: 17 May 2021

Accepted: 21 June 2021

Published: 23 June 2021

Publisher's Note: MDPI stays neutral with regard to jurisdictional claims in published maps and institutional affiliations.

Copyright: (c) 2021 by the authors. Licensee MDPI, Basel, Switzerland. This article is an open access article distributed under the terms and conditions of the Creative Commons Attribution (CC BY) license (https:// creativecommons.org/licenses/by/ $4.0 /)$.

\begin{abstract}
Extreme climatic conditions likely caused a massive fish mortality during the summer of 2001 in the St. Lawrence River. To corroborate this hypothesis, we used a physical habitat simulation approach incorporating hydraulic and water temperature models. Spawning Habitat Suitability Indices (HSI) for common carp (Cyprinus carpio) were developed using fuzzy logic and applied to the model outputs to estimate habitat weighted usable area during the event. The results revealed that areas suitable for common carp spawning (HSI > 0.3) were severely reduced by high water temperatures, which exceeded $28{ }^{\circ} \mathrm{C}$ during the mortality event. During the mortality event, the amount of suitable habitat was reduced to $<200 \mathrm{ha} /$ day, representing less than $15 \%$ of the maximum potential suitable habitat in the study reach. In addition, the availability of cooler habitats that could have been used as thermal refuges was also reduced. These results indicate that the high water temperature in spawning areas and reduced accessibility to thermal refuge habitats exposed the carp to substantial physiological and environmental stress. The high water temperatures were highly detrimental to the fish and eventually led to the observed mortalities. This study demonstrates the importance of including water temperature in habitat suitability models.
\end{abstract}

Keywords: 2D model; common carp; fish habitat; fuzzy logic; water temperature

\section{Introduction}

Understanding and quantifying the effects of habitat availability on fish populations is crucial for protecting habitats from anthropogenic pressures [1-3]. Since the mid-1970s, simple habitat preference curves have been used to represent fish habitats, allowing for the development of Habitat Suitability Indices (HSI). Such habitat predictions can be helpful to inform water resources managers, prioritize conservation decisions and contribute to environmental assessments [4-6]. The most commonly used variables for fish habitat evaluations are water depth, velocity and substratum [7]. With advances in computational power, it is becoming increasingly possible to implement spatial habitat models over large areas [8-10] and incorporate additional variables into the models, increasing their accuracy [11].

Of these additional habitat variables, there has been renewed interest in the incorporation of water temperature in fish habitat models due to its role in all aspects of fish life history, including reproduction, phenology, survival, feeding, growth, habitat selection, migration and intra- and inter-specific competition [12-15]. Water temperature has also 
been identified as a main driver of fish mortality [16-18]. As river temperatures are increasing as a consequence of anthropogenic activities [13,19-21], there is an increased need to improve understanding of the river temperature response to past and future climatic trends. A deeper understand of the drivers of thermal heterogeneity within rivers and the impact of this upon river habitats and organisms is, therefore, needed [22-25].

During June and July 2001, more than 25,000 carcasses of common carp (Cyprinus carpio) were found along $250 \mathrm{~km}$ of shoreline of the St. Lawrence River, including Lake Saint-Pierre, the fluvial lake where this study was conducted [26,27] (Figure 1). The main species affected by the mortality was the common carp. The overall amplitude of the mortality is underestimated as carcasses were only removed in inhabited areas due to the potential public health concerns of decomposing carcasses (e.g., water contamination, bacteria outbreaks, bad smell). Observations from Mingelbier et al. [28] established that mortalities were spread over a wide area and randomly distributed (i.e., the carcasses were not transported from one specific location downstream by the flow), indicating that the cause of death was most likely not a point source. The hypothesis of a localized spill or contamination causing such high mortality was, therefore, eliminated. Frequency analyses performed on hydrometeorological data in the St. Lawrence drainage basin confirmed that the elevated water temperature $\left(34^{\circ} \mathrm{C}\right)$ and low water levels measured during the summer of 2001 led to extreme conditions for fish [27,29]. Due to these extreme conditions, the common carp population was rendered immunodeficient [30] and vulnerable to bacterial infection [26]. The magnitude of the event of 2001 was significant for the ecology of the St. Lawrence River, also killing individuals from several other fish species, including those in the Catostomidae, Anguillidae, Acipenseridae, Ictaluridae, Esocidae, Percidae and Centrarchidae families, albeit in smaller numbers ( $<100$ individuals/species).

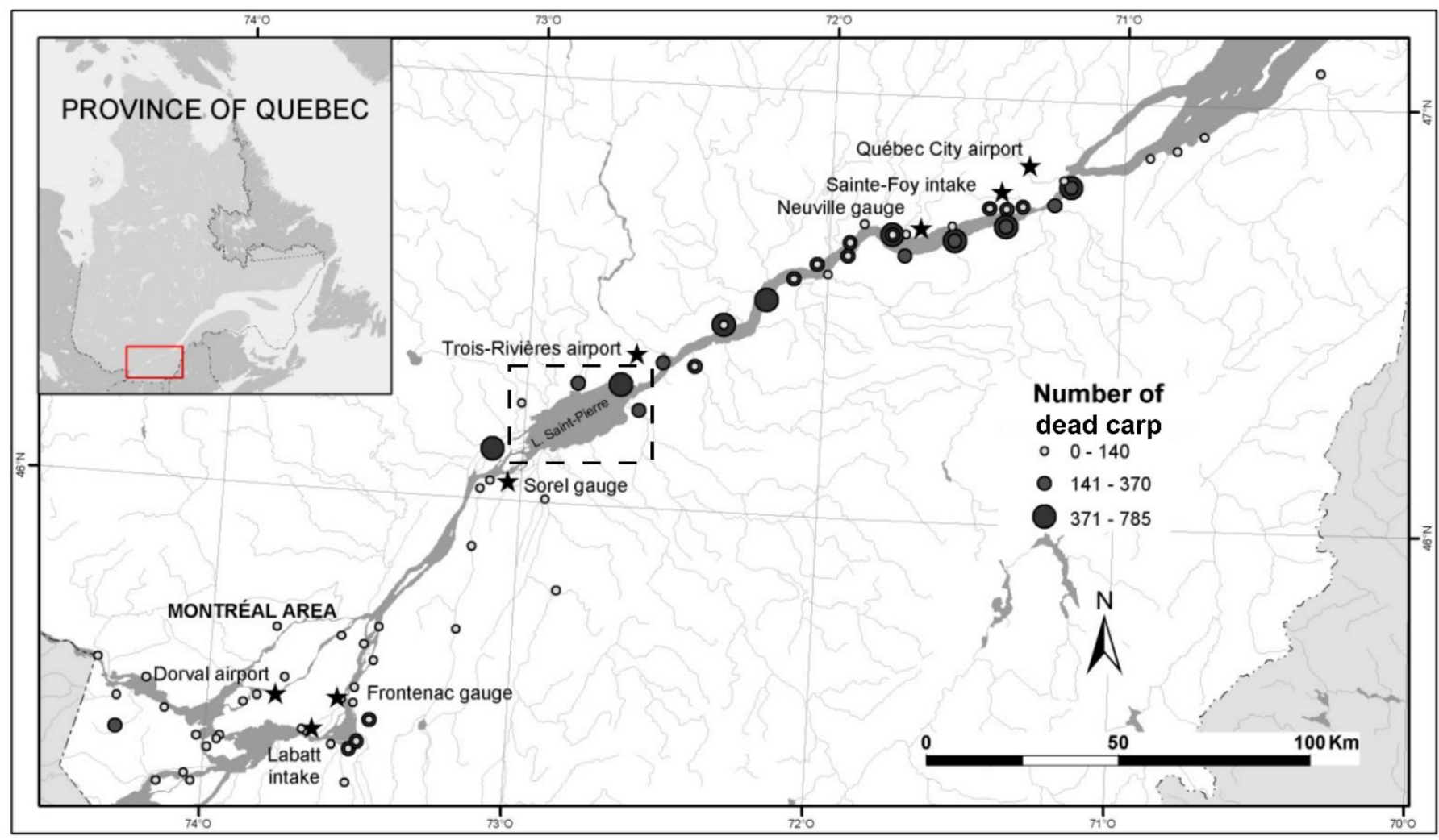

Figure 1. The freshwater course of the St. Lawrence River: locations where more than 25,000 dead common carp were collected during the mortality event of 2001 (adapted from Ouellet et al., 2010). The modeling results are shown for the Lake St. Pierre (dotted box area). 
Although Ouellet et al. [29] demonstrated that the hydroclimatic conditions of 2001 were extreme (maximum daily water temperatures with a return period of 47 years), the relative scarcity of hydrometeorological data covering the St. Lawrence River meant that it was not possible to achieve a detailed portrait of the mortality event by looking at the spatiotemporal distribution of water temperatures during the event. Given this lack of knowledge, additional information was needed to obtain a complete picture of how water temperatures in the St. Lawrence River can influence fish habitat under extreme hydroclimatic events. This paper presents the development of a spatially distributed 2D habitat model to better understand the role of water temperature in carp habitats and its role as a trigger for fish mortality during the extreme event of 2001. The specific objectives of this study were (1) to develop an HSI for common carp spawning based on a fuzzy logic approach, (2) to estimate the importance of water temperature as a carp habitat variable by exploring its spatial distribution and dynamics at different time scales and (3) to spatially and temporally quantify common carp spawning habitat during the 2001 mortality event.

\section{Materials and Methods}

\subsection{Study Site}

The St. Lawrence River, also known by its Mohawk name Kaniatarowanenneh meaning 'big waterway,' is one of the largest rivers in the world. It flows over $1000 \mathrm{~km}$ from Lake Ontario, the most downstream of the five Great Lakes, through the Canadian provinces of Ontario and Québec to the Atlantic Ocean (Figure 1). The mean annual flow at fluvial Lake St. Pierre (Sorel gauging station) is $10,333 \mathrm{~m}^{3} \mathrm{~s}^{-1}$ [31]. Water levels in the St. Lawrence River are mainly a function of discharge from its regulated and unregulated tributaries [32], which results in contrasting water body characteristics (water temperature, water color, turbidity, conductivity, etc.). In the St. Lawrence River, inputs from these tributaries generate distinct water masses [32]. These different water sources flow side by side for hundreds of kilometers with minimal lateral mixing, generating important gradients between fish habitats. The river's morphology is highly variable, and the flow is mainly concentrated in a large navigation channel (depth $\geq 11.3 \mathrm{~m}$ and width $\geq 230 \mathrm{~m}$ ) [33]. The St Lawrence's average width is approximately $2.5 \mathrm{~km}$, although it varies between $\sim 800 \mathrm{~m}$ at its narrowest point to $\sim 15 \mathrm{~km}$ within three fluvial lakes [32]. These fluctuations between wide and narrow reaches affect the velocity and water temperature cooling and warming processes.

We focus on Lake St. Pierre, where most common carp spawning habitats are located [29]. This section of the St. Lawrence River results in a natural river widening, with a mean depth of $3 \mathrm{~m}$ and a low surface slope. Those characteristics, combined with low velocity, long transit time (18 days) and high aquatic vegetation density (shallow and deep marshes) near the shoreline, enhance residence times [9,34]. The water temperature regime of the St. Lawrence River is highly variable over space due to this complex morphology [34].

\subsection{Hydrodynamic Simulations as Input for a Habitat Model}

An existing coupled hydrodynamic-water temperature model (H2D2) $[35,36]$ was used to produce the basic data that served as input for the spawning habitat model at daily time steps. The model was developed and tested over the entire fluvial reach of the St. Lawrence River and shows good predictive power [9,37,38]. It uses detailed topography, bathymetry and a substratum description of the floodplain and riverbed to simulate the hydrodynamics on a high-resolution finite element mesh for specific discharge scenarios. H2D2 was calibrated and validated against the measured flow, velocity and water temperature datasets and was used to simulate real-time hydrodynamic conditions for the St. Lawrence River [31,34].

H2D2 was run using discharge conditions from 2001 in order to simulate depth, velocity, vegetation density [37] and water temperatures corresponding to the time period surrounding the carp mortality event. For subsequent computations, these environmental 
variables were transferred to a regular grid containing 160,000 nodes with an average density of one point every $80 \mathrm{~m}$ (varying from $60-200 \mathrm{~m}$ depending on local bathymetry). All information from the 2D simulations was interpolated to this modeling grid using a nearest neighbor approach. The grid covered the entire floodplain of the St. Lawrence River and simulated water temperature data as inputs for the spawning habitat model.

\subsection{Habitat Variables}

Four key variables were selected to characterize the common carp spawning habitat based on the literature for the St. Lawrence River [38,39]. The common carp generally spawns in relatively shallow water areas $(<2 \mathrm{~m})$, where velocity is almost null, and plants or debris suitable for use as egg support are present [40]. Therefore, water depth (m), vegetation density $(\%)$ and velocity $(\mathrm{m} / \mathrm{s})$ were selected as environmental variables to represent the spawning habitat. In addition, the inclusion of water temperature as a habitat variable was tested to evaluate its contribution in estimating common carp spawning areas.

The common carp spawning period (based on McCrimmon [38] and specifically for the St. Lawrence River) starts when the water temperature reaches a threshold of $17^{\circ} \mathrm{C}$ (with an optimal value between $18^{\circ} \mathrm{C}$ and $23^{\circ} \mathrm{C}$ ). At around $26^{\circ} \mathrm{C}$, the spawning activity decreases, stopping completely at $28^{\circ} \mathrm{C}$. Water temperatures exceeding $34^{\circ} \mathrm{C}$ are lethal for the common carp [9]. It was hypothesized that access to thermal refuges was limited during the carp spawning period of 2001. This was explored by including thermal refuge habitat within the model. A search was conducted for cooler areas in the immediate vicinity of thermally unsuitable spawning habitat. As no specific information was available in the literature concerning thermal refuges for common carp, the optimal water temperature for spawning activity $\left(<23^{\circ} \mathrm{C}\right)$ was used to define what could be considered as cool recovery habitat where fish could potentially recuperate or avoid the warmer areas. The optimal temperature for spawning was used since this threshold involves no negative physiological thermal stress, and therefore, temperatures below this threshold should be suitable for fish recovery.

\subsection{Habitat Modeling Using Fuzzy Logic}

The fuzzy logic approach transparently mimics human reasoning by describing habitat characteristics with linguistic labels such as 'low' depth or 'high' velocity, rather than numeric ones [41,42]. For example, people generally have an individual perception of what shallow water means; however, it may be challenging to be specific about the exact upper limits of this category, as such a value may be considered shallow by some and intermediate by others. Furthermore, fuzzy logic was developed to represent gradual changes in categories (i.e., shallow to intermediate depth) for a given variable that are not necessarily mutually exclusive rather than using exclusive thresholds based on a dichotomic classification. Therefore, unlike Boolean logic (true or false, 0 or 1 ), fuzzy logic allows for the relaxation of the classification criteria by associating a specific numerical value of a given variable with various degrees of membership to more than one category simultaneously [43]. In this way, if a depth value of $0.45 \mathrm{~m}$ is at the boundary between shallow and medium depth in traditional Boolean logic, $0.45 \mathrm{~m}$ will represent the threshold between those two categories in traditional HSI. However, in fuzzy logic, the transition between categories is gradual, meaning that values between $0.4 \mathrm{~m}$ and $0.5 \mathrm{~m}$, for example, could be part of both shallow and intermediate categories (Figure 2).

Because quantitative descriptions of common carp spawning habitats are scarce in the literature and mainly based on expert knowledge, fuzzy logic was deemed the most appropriate approach to develop a habitat suitability index based on specific common carp habitat requirements [40]. Fuzzy logic and its various uses in habitat models are detailed in [41,43]. A fuzzy HSI offered the following advantages: (1) is it particularly well suited for the description of categories of habitat variables that may not be fully mutually exclusive, given the natural variability and model uncertainty, and (2) it allows for the incorporation of information from different sources (e.g., quantitative, qualitative and 
expert knowledge from scientific and angling literature). This approach requires (1) the development of univariate fuzzy habitat suitability criteria (equivalent to habitat suitability curves in conventional models) for key variables, (2) the definition of a composite HSI using these key variables and so-called fuzzy rules and (3) the simulations of the key variables for the conditions measured in 2001.
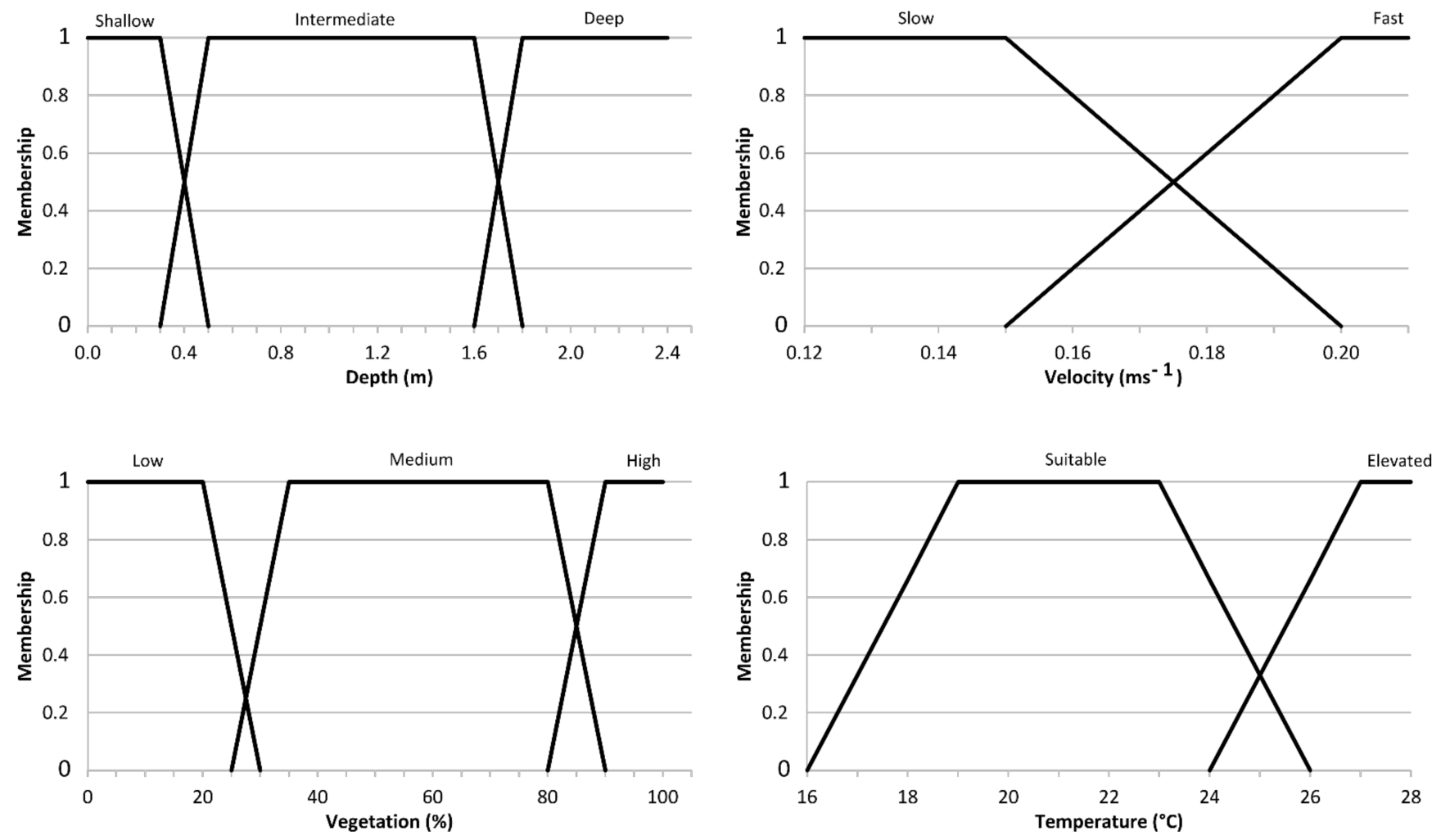

Figure 2. Linguistic values and membership functions for each variable used in carp spawning habitat calculation.

The development of an HSI based on fuzzy logic was completed as follows: the first step is called fuzzification, where each variable category is transformed into a linguistic value called a 'fuzzy set' [44,45] (for example, a water depth $<0.3 \mathrm{~m}$ will be categorized as "shallow") (Figure 2). The second step consists of developing a simple model defining each needed category of habitat variable via a membership function (linear, Gaussian, etc.). Third, each possible combination of the different variable categories defined in step 1 are articulated in a set of IF-THEN rules, and for each rule, a consequent habitat suitability is assigned (for example, if the depth is shallow, and if the velocity is slow, and if the vegetation density is medium, and if the water temperature is adequate, then HSI is high). This third step must be repeated when modifying a variable or the variable combinations. Finally, the defuzzification step enables the conversion of the final HSI linguistic values back to numerical ones, enabling HSI calculation. For this last step, the center of gravity (COG) was used [44].

\subsection{Water Temperature Scenarios, Habitat Suitability and Habitat Availability}

To evaluate the contribution of water temperature as a habitat variable for the common carp and to compare available spawning areas and habitat suitability under contrasting conditions, two scenarios were computed (A and B), both of which included water depth, velocity and vegetation density based on the flow conditions measured in 2001. Scenario A excluded water temperature altogether, and Scenario B simulated water temperature data for 2001. HSI values (0-1) calculated in each grid cell under each scenario were mapped across the study area to represent the suitability of the common carp spawning habitat. An HSI value of 0 means that there was no suitable habitat. HSI values $>0$, and $\leq 0.3$ 
were considered as poor habitat quality; Values $>0.31$ and $\leq 0.7$ were classified as medium habitat quality (suitable), and values $>0.7$ corresponded to good habitat (highly suitable, showing the best conditions for spawning).

To better represent the variation in habitat availability between the two scenarios, weighted usable habitat areas (WUA in ha/day) were calculated as follows: WUA = $\sum($ HSI values $\times$ geid cell area $)$.

Results of the spawning habitat simulations comprised HSI values (0 to 1 ) distributed across the study area at each time step and daily WUA.

\subsection{Simulation Periods}

For the purposes of this study, simulations were computed at a daily time step between 24 May (when water temperature reached the threshold deemed adequate for carp spawning, i.e., $17^{\circ} \mathrm{C}$ in most of the shallow water areas) and 31 July, two weeks after the peak in mortality. The WUA showed the results for the entire simulation period. However, given the large amount of data produced, the spatially distributed habitat variables (input variables and HSI) are presented for two dates: 1 June, corresponding to the period preceding the mortality event, and 15 July, corresponding to the peak mortality event; both dates cover the spawning period for the common carp. In addition, the results are only presented for the Lake St. Pierre, where most common carp spawning habitats are located [29]. These results are representative of other shallow spawning habitats used by the carp elsewhere.

\section{Results}

\subsection{Hydrodynamic Simulation of the 2001 Study Period}

The hydrodynamic model simulated the four habitat variables daily as a function of environmental conditions measured during the summer of 2001. Between 1 June and 15 July (Figure 3), discharge decreased from $8171 \mathrm{~m}^{3} / \mathrm{s}$ to $7101 \mathrm{~m}^{3} / \mathrm{s}$, leading to a reduction in both water depth and velocity. Such a decrease is typically observed later during the summer period, but during the summer of 2001, this decrease occurred substantially earlier in the season, resulting in a water level decrease of $0.4 \mathrm{~m}$ in Lake St. Pierre between June and July. In shallow habitats, the velocity also decreased from $0.4-0.2 \mathrm{~m} / \mathrm{s}$ in June to below $0.2 \mathrm{~m} / \mathrm{s}$ in July. Vegetation density, which is driven in part by velocity and water depth, did not differ significantly between the two periods. Water temperature values were on average below $22{ }^{\circ} \mathrm{C}$ in May and rapidly increased after 1 June, reaching the common carp's spawning thermal limit of $26-28^{\circ} \mathrm{C}$ by 15 July.

\subsection{Usable Habitat Area}

To illustrate the temporal change in areas of usable spawning habitat, daily WUAs were computed for scenario A and B between 24 May and 31 July (Figure 4). Scenario A had consistently higher values of WUA, and the differences in WUA were greater during the warmer days. In scenario B, the calculated daily WUAs are systematically lower (mean of $4277 \mathrm{ha}$, with minimum and maximum values of 31 ha and $8830 \mathrm{ha}$ ) than for scenarios A (mean of 7028 ha, minimum 4494 ha, maximum 9180 ha). The smallest amount of useable habitat under scenario B was reached on 27 May 2001, revealing critical periods during which minimal suitable spawning habitat was available (e.g., 27-30 May; 1-4 June) due to a high water temperature $\left(>26^{\circ} \mathrm{C}\right)$ in about $90 \%$ of the shallow areas. Fewer spawning habitat areas were available under scenario $B$, with 11 days of the time series exhibiting daily values $<200$ ha and 24 days with values $<1000$ ha. WUAs calculated for scenario B were lower ( 25 to $47 \%$ ) than those calculated for scenario A. 



Figure 3. Spatial distribution of the habitat variables $(\mathbf{A})$ depth $(\mathrm{m}),(\mathbf{B})$ velocity $(\mathrm{m} / \mathrm{s}),(\mathbf{C})$ vegetation relative density $(\%)$ and $(\mathbf{D})$ water temperature $\left({ }^{\circ} \mathrm{C}\right)$, used in the model simulating carp spawning habitat in the Lake Saint-Pierre area. Two examples are presented for the year 2001: during the spawning period preceding the mortality event (1 June) and during the fish mortality (15 July). 


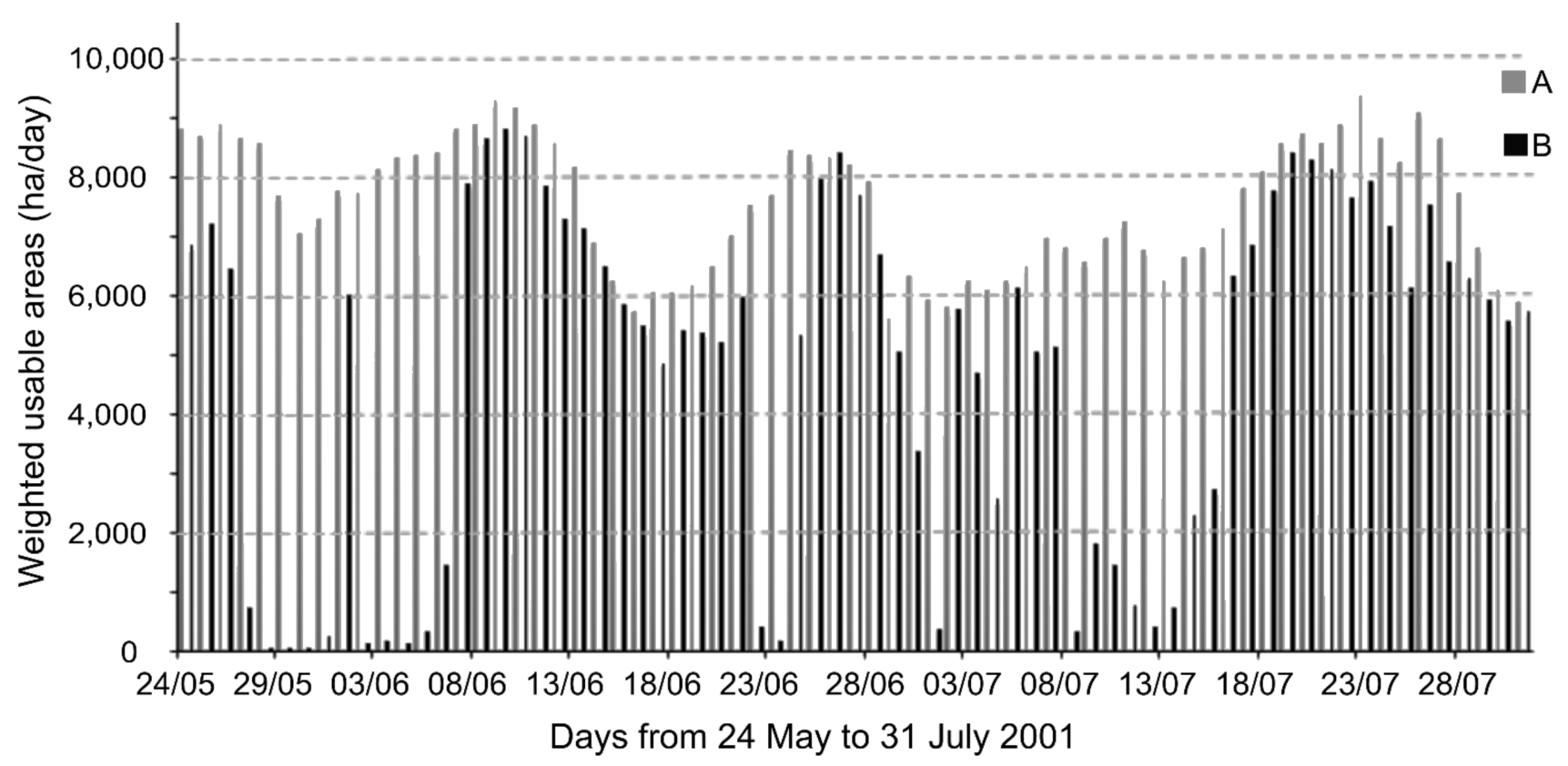

Figure 4. Daily weighted usable areas (WUA ha) between 24 May and 31 July corresponding to carp spawning habitat available in the freshwater river reach between Lake St. Louis and Trois-Rivières. Values were computed for two scenarios: (A; medium grey) excluding water temperature and (B; black) including water temperature as simulated for 2001.

\subsection{Habitat Suitability}

The common carp spawning habitat was mapped for scenarios A (excluding water temperature as a habitat variable) and B (water temperature as simulated in 2001), and for 1 June (pre-mortality; Figure 5) and 15 July (mortality event peak; Figure 6). A comparison of the two scenarios revealed a high degree of contrast between the distributions of suitable spawning habitat (HSI values) for both dates. These inter-scenario differences were constant across both dates (1 June and 15 July), with June having a higher quantity of HSI values classified as 'good' habitat quality. For the two dates (1 June and 15 July), areas with a water depth $<0.8 \mathrm{~m}$, a velocity $<0.1 \mathrm{~m} / \mathrm{s}$ and a vegetation density around $40-90 \%$ were designated as suitable for common carp spawning.

Scenario A exhibited a greater quantity of HSI values classified as 'good' habitat quality on 1 June compared to 15 July, when floodplain habitats were no longer available due to decreasing water levels. This shift in the spatial habitat distribution between the two dates was observed for the two scenarios. Overall, for both dates, a greater area and more suitable spawning areas occurred in scenario A, which excludes the influence of water temperature. Mean HSI values were over 0.71 for more than $90 \%$ of the potential spawning habitat area and always exceeded 0.3 (medium habitat quality). Scenario A showed that HSI values above 0.31 (medium quality) were mainly located in shallow waters (depth $<0.5 \mathrm{~m}$ ) and represent between 40 and $70 \%$ of the available area, while HSI values below 0.3 (poor quality) were principally located in areas where the other habitat variables became limiting (i.e., depth $>1.2 \mathrm{~m}$, current velocities $>0.2 \mathrm{~m} / \mathrm{s}$ and vegetation densities $<40 \%$; Figure 3). However, for scenario B (2001 simulated water temperature conditions), HSI values dropped below 0.3 in areas where the other scenarios showed higher HSI values. Habitats classified as 'medium' or 'good' quality were almost completely absent $(<10 \%$ of the available area) in scenario B. These overall observations were similar for the two dates. 
1 June, discharge $8,171.38 \mathrm{~m}^{3} \cdot \mathrm{s}^{-1}$

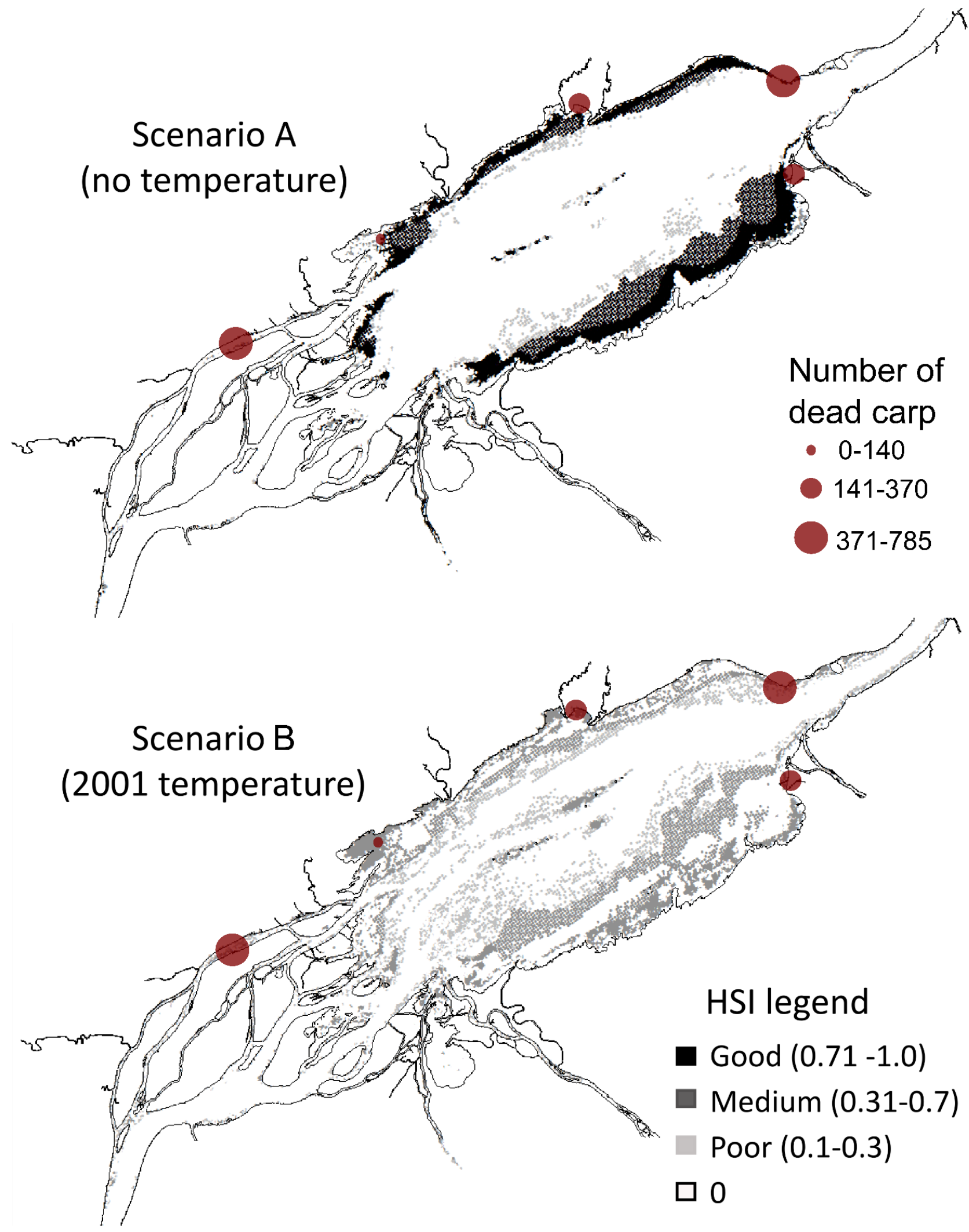

Figure 5. Spatial distribution of habitat suitability index (HSI) for the carp spawning habitat in the Lake Saint-Pierre area simulated for 1 June 2001, during the mortality period. Two scenarios were computed: (A) excluding water temperature and (B) including water temperature as simulated for 2001. 


\section{July, discharge $7,101.72 \mathrm{~m}^{3} \cdot \mathrm{s}^{-1}$}

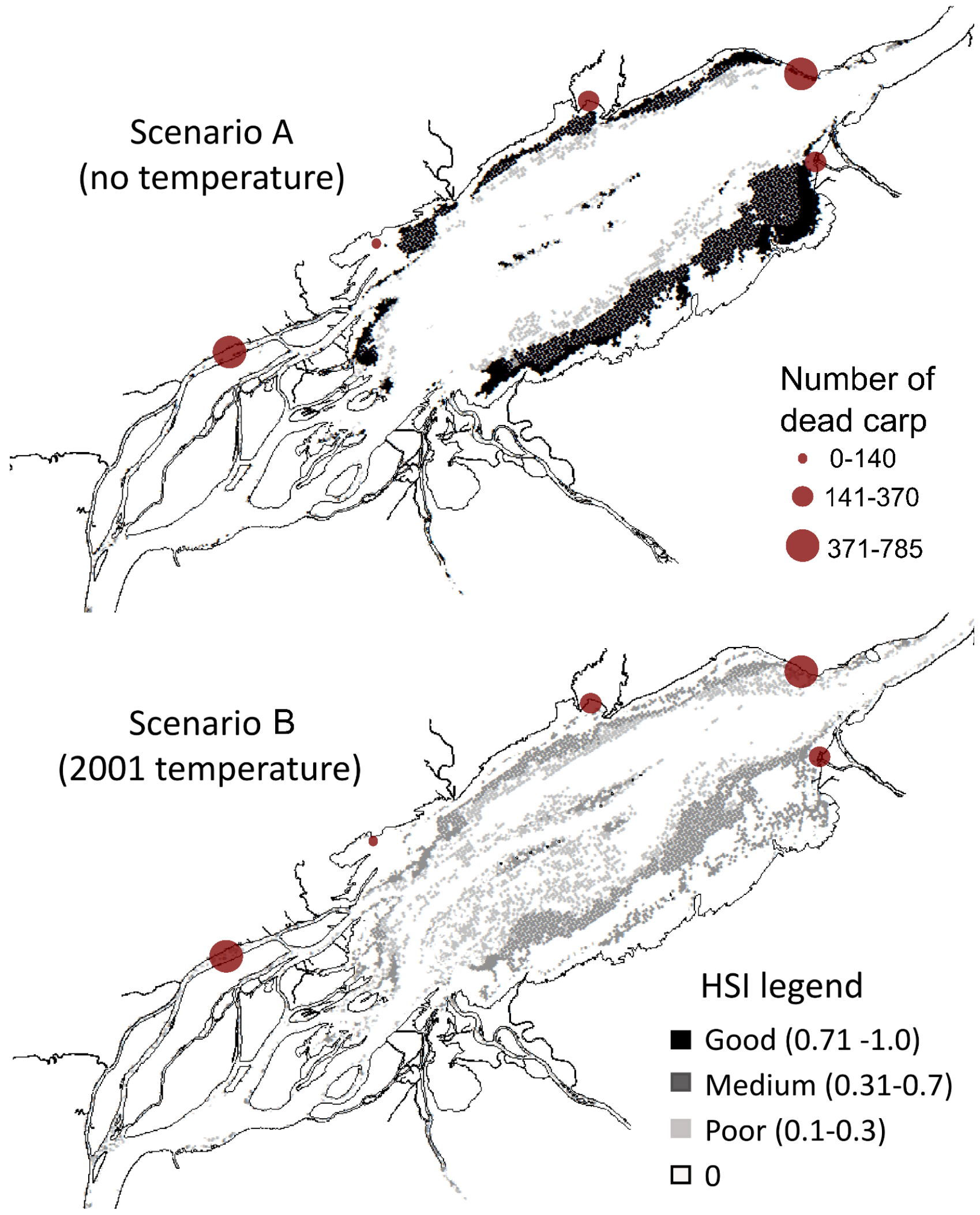

Figure 6. Spatial distribution of habitat suitability index (HSI) for the carp spawning habitat in the Lake Saint-Pierre area simulated for 15 July 2001, a few days before the mortality event began. Two scenarios were computed: (A) excluding water temperature and (B) including water temperature as simulated for 2001. 
The comparison of the different input variables (Figure 3) highlighted that water temperature was mostly limiting in scenario $B$ and explained the differences observed between the scenarios. Scenario B showed that areas that were identified as suitable in A were, in fact, affected by water temperatures over $26^{\circ} \mathrm{C}$ on June 1 st and were subsequently exposed to a rapid and prolonged warming, reaching temperatures up to $28^{\circ} \mathrm{C}$ by $15 \mathrm{July}$. The shallowest habitats were even warmer, often exceeding $28^{\circ} \mathrm{C}$. The water temperature reached the upper limit for common carp spawning $\left(>28^{\circ} \mathrm{C}\right)$ over more than $20 \%$ of the available spawning habitat. Areas with cooler temperatures were available only in water depths $>1.6 \mathrm{~m}$, where the velocity exceeded general spawning common carp habitat requirements $(<0.2 \mathrm{~m} / \mathrm{s})$. The daily simulations showed that on some days, $100 \%$ of the potentially available spawning habitat was affected by water temperatures exceeding $28^{\circ} \mathrm{C}$, meaning that spawning habitats were no longer suitable for the fish, as shown in Figure 4 (Section 3.2).

\section{Discussion}

\subsection{Habitat Suitability and Availability}

The present study showed how adverse temperature conditions limited the availability of suitable spawning habitats for the common carp. As revealed by the series of simulations between 24 May and 31 July, suitable spawning habitat areas were sometimes drastically reduced to between 0 and $<200$ ha in Lake Saint-Pierre during four different periods of 3-4 consecutive days. During those periods, it is not only habitat quantity (i.e., area) that was affected, but also habitat quality. Indeed, on occasion, less than $10 \%$ of available habitat was suitable, with a majority of the HSI values being lower than 0.30 as temperatures approached a and even exceeded $28^{\circ} \mathrm{C}$. Under less extreme conditions, it is possible that the spawning habitat would have been available in sufficient quantity for all individuals of a specific population to access it and reproduce. However, since spawning itself requires higher energy demands, fish reproducing in poor quality habitats may be subjected to higher stress [46], which can eventually result in reduced reproductive success [46-48].

\subsection{Access to Thermal Refuges}

A closer inspection of the simulations was helpful in examining spatio-temporal patterns in the data and understand the water temperature dynamics in the shallow habitat where common carp were present. The water temperature simulations revealed that shallow habitats were susceptible to water temperature, exhibiting daily water temperature pulses (e.g., strong warming trend during the day, followed by cooling at night) along the shores, especially in the large and shallow fluvial Lake Saint-Pierre. Shallow habitats, which warm fast, were the first to be affected by high water temperatures. Moreover, given the magnitude and duration of the climate event in 2001, the high temperatures rapidly affected deeper habitats, where the velocities were close to common carp swimming capacities [40]. Only the main channel (Figure 3), where the flow is concentrated and can reach $10,000 \mathrm{~m}^{3} \mathrm{~s}^{-1}$, stayed cooler. It is unlikely that these habitats were used, as the navigation channel of Lake St. Pierre is known to represent an obstacle to fish movements (Quebec Wildlife Department, unpublished data). This meant that this deep-water habitat, the only remaining zone of cool water, could not serve as a thermal refuge, likely further increasing thermal stress.

During fieldwork, carp were observed systematically moving towards spawning habitat early in the morning, suggesting that fish spawned during the day but did not spend the entire day in the same type of habitat. Since the typical spawning habitat for the common carp is shallow and exposed to high temperature, it was hypothesized that carp were resting during the night in deeper and cooler habitats with higher dissolved oxygen concentrations. However, in June 2001, these areas of cool habitat $\left(<23^{\circ} \mathrm{C}\right)$ were scarce, patchy and mostly in areas where current velocities were $>0.2 \mathrm{~m} / \mathrm{s}$ in or near the navigation channel. In addition, they were located far from the spawning grounds. This suggests that fish were mainly restricted to warm habitats $\left(>28^{\circ} \mathrm{C}\right)$, with little or no access to thermal 
refuges. Whether they attempted to spawn or not is unknown, but field observations indicated that they were trapped in these spawning habitats, further reducing the potential for behavioral thermoregulation. This most likely resulted in additional physiological stress that contributed to the mass mortality event.

This raises questions about the likely inability of spawning common carp to access a thermal refuge habitats and highlights the importance of habitat connectivity between shallow habitats for spawning (during daylight) and cooler habitats for resting (during the night). The habitats of fluvial environments are receiving an increasing research focus [49-52]. Such information would have greatly contributed to the present study by providing important information on the common carp behavioral thermoregulation via the use of thermal refuges and how connectivity between habitats affected their capacity to do so. This highlights the need for a better understanding of connectivity impacts in aquatic ecosystems and future investigations incorporating fish swimming capacity, specific habitat requirements and actual field conditions. This would likely provide useful information for fish managers to identify and protect a series of critical habitats.

\subsection{Limitations and Improvements}

We believe that fuzzy logic, which can deal with qualitative habitat descriptions and a degree of uncertainty (e.g., overlaps between variable categories, diverse information sources or different fuzzy sets or scenarios) was particularly well-adapted to the present study given the limited published information concerning common carp habitat and the subsequent necessity to supplement these data with information from professional anglers.

Although we attempted to obtain field data on carp movements and habitat use using biotelemetry techniques, it was not feasible to complete field validation in such a large aquatic ecosystem (over 35,300 ha). Despite this, the predicted spawning areas for carp were in general agreement with our field observations (unpublished data from the Quebec Department of Fauna and Natural Resources), indicating that the habitat preferences used in the present model were realistic. Given that the objective of this study was to show the role of water temperature as a factor limiting the availability and quality of spawning habitat, possible model biases are less of a concern.

This study shows that the use of multi-variable models can help to create more realistic scenarios, as long as the selected variables increase the model's predictive power. There is a trade-off between increasing the number of variables, computational power and the model's transferability. The selection of the variables should always be guided by avoiding redundancy (e.g., by examining variable collinearity), parsimonious selection of the input variables (e.g., via sensitivity analysis) and ensuring that selected variables are attuned to the hypotheses of the study. Our results clearly showed that the development of a 2D spawning habitat model that included water temperature provided a better understanding of the role of temperature as a limiting factor in spawning habitat availability and quality during the 2001 carp mass mortality event in the St. Lawrence River. The addition of water temperature as a habitat variable allowed us to better define the spatial limits of essential habitats for common carp spawning. Although it was not possible to directly quantify the links between water temperature and the mortality event or other water quality parameters (such as dissolved oxygen) due to lack of data, our results clearly indicate that fish were exposed to elevated water temperatures and that the available habitats and access to thermal refuges were reduced, likely driving a substantial increase in thermal stress. This probably added to the existing stresses related to the spawning pressure (an additional metabolic stressor) and potentially low dissolved oxygen (due to elevated water temperature). The development of a cumulative stress model could help to fully understand how those stressors interacted and increased the overall ecophysiological stress to further explain the contribution of the thermal stress.

Given that water temperature is a major influence on aspects of fish life cycles and the fact that thermal stress on aquatic organisms will likely increase under future climatic change, there is an urgent need to anticipate the consequences of future temperature 
changes on different aquatic ecosystem components. This could be achieved through 2D water temperature modeling. Such models could be adapted to other species and for other aquatic ecosystems, for example (1) to map thermal refuges for evaluating potential mortality in winter or summer, (2) to map the length of the growing season relative to the fish productivity of a specific region, (3) to map the potential distribution areas for harvested species or the expansion potential of invasive species, (4) to better understand the effects on fish phenology, particularly the onset of spawning, and (5) to develop various applications such as the role of extreme temperatures that could act as a barrier to fish habitat connectivity.

\section{Conclusions}

Our study highlights the importance of including water temperature in habitat suitability models. The 'control' simulation, characterizing a common carp habitat in 2001 using depth, velocity and vegetation as habitat variables but excluding temperature (scenario A), predicted large areas of suitable habitats for common carp spawning. However, this result largely reflects the fact that the non-inclusion of temperature in the habitat model results in a substantial overestimation of common carp spawning habitats in comparison to the 'real' availability of suitable habitat available in the summer of 2001. Indeed, when water temperature is included in the model (scenario B), most of the habitat area simulated in scenario A was shown to be unsuitable during the summer of 2001. Results from scenario B corroborate the major detrimental effect of a high water temperature on carp spawning habitats during the summer of 2001 at a large spatial scale.

It is hoped that the present paper underlines the advantage and potential of including the temperature in the set of fish habitat variables, that the results will be useful to river managers and that the results will stimulate new avenues of research. Such research can inform fisheries management, with the ultimate goal of developing a better understanding and a better level of protection of fish habitats, as well as providing important information on the resilience potential of aquatic ecosystems.

Author Contributions: Conceptualization, V.O., A.S.-H., Y.S., M.M. and J.M.; methodology, V.O., A.S.-H. and J.M.; validation, V.O.; formal analysis, V.O.; investigation, V.O., A.S.-H., Y.S., M.M. and J.M.; data curation, V.O.; writing—original draft preparation, V.O., A.S.-H. and S.J.D.; writingreview and editing, Y.S., M.M., J.M.; visualization, V.O. and S.J.D.; supervision, A.S.-H., Y.S., M.M. and J.M.; project administration, V.O. and A.S.-H.; funding acquisition, V.O. and A.S.-H. All authors have read and agreed to the published version of the manuscript.

Funding: This research was funded by the Fonds de recherche du Québec-Nature et technologies (FRQNT) for V.O.

Institutional Review Board Statement: Not applicable.

Institutional Consent Statement: Not applicable.

Data Availability Statement: Restrictions apply to the availability of these data. Data were obtained from Environment Canada and data request can be made to J.M. with the permission of V.O.

Acknowledgments: The authors would like to thank everybody involved in the fieldwork and especially Paul Messier de la Maison du Marais, whose assistance in tagging and following the fish represented a tremendous effort.

Conflicts of Interest: The authors declare no conflict of interest.

\section{References}

1. Comte, L.; Grenouillet, G. Do stream fish track climate change? Assessing distribution shifts in recent decades. Ecography 2013, 36, 1236-1246. [CrossRef]

2. Pont, D.; Logez, M.; Carrel, G.; Rogers, C.; Haidvogl, G. Historical change in fish species distribution: Shifting reference conditions and global warming effects. Aquat. Sci. 2015, 77, 441-453. [CrossRef] [PubMed]

3. Justice, C.; White, S.M.; McCullough, D.A.; Graves, D.S.; Blanchard, M.R. Can stream and riparian restoration offset climate change impacts to salmon populations? J. Environ. Manag. 2017, 188, 212-227. [CrossRef] [PubMed] 
4. Haro, A.; Chelminski, M.; Dudley, R.W. Computational Fluid Dynamics-Habitat Suitability Index (CFD-HSI) Modelling as an Exploratory Tool for Assessing Passability of Riverine Migratory Challenge Zones for Fish. River Res. Appl. 2015, 31, 526-537. [CrossRef]

5. Dunn, C.G.; Angermeier, P.L. Development of Habitat Suitability Indices for the Candy Darter, with Cross-Scale Validation across Representative Populations. Trans. Am. Fish. Soc. 2016, 145, 1266-1281. [CrossRef]

6. Roy, M.L.; Le Pichon, C. Modelling functional fish habitat connectivity in rivers: A case study for prioritizing restoration actions targeting brown trout. Aquat. Conserv. Mar. Freshw. Ecosyst. 2017, 27, 927-937. [CrossRef]

7. Bain, M.B.; Jia, H. A habitat model for fish communities in large streams and small rivers. Int. J. Ecol. 2012, 2012. [CrossRef]

8. Lamouroux, N.; Capra, H. Simple predictions of instream habitat model ouputs for target fish populations. Freshw. Biol. 2002, 47, 1543-1556. [CrossRef]

9. Mingelbier, M.; Brodeur, P.; Morin, J. Spatially explicit model predicting the spawning habitat and early stage mortality of Northern pike (Esox lucius) in a large system: The St. Lawrence River between 1960 and 2000. Hydrobiology 2008, 601, 55-69. [CrossRef]

10. Deweber, J.T.; Wagner, T. Predicting Brook Trout Occurrence in Stream Reaches throughout their Native Range in the Eastern United States. Trans. Am. Fish. Soc. 2014, 144, 11-24. [CrossRef]

11. Kolden, E.; Fox, B.D.; Bledsoe, B.P.; Kondratieff, M.C. Modelling Whitewater Park Hydraulics and Fish Habitat in Colorado. River Res. Appl. 2016, 32, 1116-1127. [CrossRef]

12. Robinson, J.M.; Josephson, D.C.; Weidel, B.C.; Kraft, C.E. Influence of Variable Interannual Summer Water Temperatures on Brook Trout Growth, Consumption, Reproduction, and Mortality in an Unstratified Adirondack Lake. Trans. Am. Fish. Soc. 2010, 139, 685-699. [CrossRef]

13. Isaak, D.J.; Wollrab, S.; Horan, D.; Chandler, G. Climate change effects on stream and river temperatures across the northwest U.S. from 1980-2009 and implications for salmonid fishes. Clim. Change 2012, 113, 499-524. [CrossRef]

14. Dugdale, S.J.; Bergeron, N.E.; St-Hilaire, A.A.A. Temporal variability of thermal refuges and water temperature patterns in an Atlantic salmon river. Remote Sens. Environ. 2013, 136, 358-373. [CrossRef]

15. Corey, E.; Linnansaari, T.; Cunjak, R.A.; Currie, S. Physiological effects of environmentally relevant, multi-day thermal stress on wild juvenile Atlantic salmon (Salmo salar). Conserv. Physiol. 2017, 5, 1-13. [CrossRef]

16. Durham, B.W.; Wilde, G.R.; Pope, K.L. Temperature-caused fish kill in a flowing great plains river. Southwest. Nat. 2006, 51, 397-401. [CrossRef]

17. Chen, Y.J.; Nicholson, E.; Cheng, S.T. Using machine learning to understand the implications of meteorological conditions for fish kills. Sci. Rep. 2020, 10, 1-13. [CrossRef]

18. Schakau, V.; Hilker, F.M.; Lewis, M.A. Fish disease dynamics in changing rivers: Salmonid Ceratomyxosis in the Klamath River. Ecol. Complex. 2019, 40, 100776. [CrossRef]

19. Mohseni, O.; Stefan, H.G. Stream temperature/air temperature relationship: A physical interpretation. J. Hydrol. 1999, 218, 128-141. [CrossRef]

20. Van Vliet, M.T.H.; Franssen, W.H.P.; Yearsley, J.R.; Ludwig, F.; Haddeland, I.; Lettenmaier, D.P.; Kabat, P. Global river discharge and water temperature under climate change. Glob. Environ. Chang. 2013, 23, 450-464. [CrossRef]

21. Haddeland, I.; Heinke, J.; Biemans, H.; Eisner, S.; Flörke, M.; Hanasaki, N.; Konzmann, M.; Ludwig, F.; Masaki, Y.; Schewe, J.; et al. Global water resources affected by human interventions and climate change. Proc. Natl. Acad. Sci. USA 2014, 111, 3251-3256. [CrossRef] [PubMed]

22. Benjankar, R.; Tonina, D.; McKean, J.A.; Sohrabi, M.M.; Chen, Q.; Vidergar, D. Dam operations may improve aquatic habitat and offset negative effects of climate change. J. Environ. Manag. 2018, 213, 126-134. [CrossRef] [PubMed]

23. Webb, B.W.; Hannah, D.M.; Moore, R.D.; Brown, L.E.; Nobilis, F. Recent advances in stream and river temperature research. Hydrol. Process. 2008, 22, 902-918. [CrossRef]

24. Wilby, R.L.; Orr, H.; Watts, G.; Battarbee, R.W.; Berry, P.M.; Chadd, R.; Dugdale, S.J.; Dunbar, M.J.; Elliott, J.A.; Extence, C.; et al. Evidence needed to manage freshwater ecosystems in a changing climate: Turning adaptation principles into practice. Sci. Total Environ. 2010, 408, 4150-4164. [CrossRef]

25. Ouellet, V.; St-Hilaire, A.; Dugdale, S.J.; Hannah, D.M.; Krause, S.; Ouellet-P, S.; Proulx-Ouellet, S. River temperature research and practice: Recent challenges and emerging opportunities for managing thermal habitat conditions in stream ecosystems. Sci. Total Environ. 2020, 736, 139679. [CrossRef]

26. Monette, S.; Dallaire, A.D.; Mingelbier, M.; Groman, D.; Uhland, C.; Richard, J.-P.; Paillard, G.; Johannson, L.M.; Chivers, D.P.; Ferguson, H.W.; et al. Massive mortality of common carp (Cyprinus carpio carpio) in the St. Lawrence River in 2001: Diagnostic investigation and experimental induction of lymphocytic encephalitis. Vet. Pathol. 2006, 43, 302-310. [CrossRef]

27. Ouellet, V.; Mingelbier, M.; Saint-Hilaire, A.; Morin, J. Frequency analysis as a tool for assessing adverse conditions during a massive Fish Kill in the St. Lawrence River, Canada. Water Qual. Res. J. Can. 2010, 45. [CrossRef]

28. Mingelbier, M.; Trencia, G.; Dumas, R.; Dumas, B.; Mailhot, Y.; Bouchard, C.; Manolesco, D.; Brodeur, P.; Hudon, C.; Ouellettte, G. Avis Scientifique Concernant la Mortalité Massive des Carpes dans le Saint Laurent Durant l'été 2001; Societe de la faune et des parcs du Quebec, Ministere de l'environnement: Quebec, Canada, 2001; Volume 26. 
29. Ouellet, V.; St-Hilaire, A.; Mingelbier, M.; Morin, J. Temperature duration frequency analysis on the St. Lawrence River (Canada)-A tool for quantifying adverse conditions during the 2001 massive fish kill. Water Qual. Res. J. Can. 2010, 45, 47-57. [CrossRef]

30. Ouellet, V.; Pierron, F.; Mingelbier, M.; Fournier, M.; Fournier, M.; Couture, P. Thermal Stress Effects on Gene Expression and Phagocytosis in the Common Carp (Cyprinus Carpio): A Better Understanding of the summer 2001 st. Lawrence River Fish Kill. Open Fish. Sci. J. 2013, 6, 99-106. [CrossRef]

31. Morin, J.; Bouchard, A. Les bases de la modélisation du tronçon Montréal/Trois-Rivières. Rapport scientifique SMC-Hydrométrie RS-100; Service meteorologique du Canada, Monitoring et Technologies, Section: Sainte-Foy, Canada, 2000.

32. Frenette, J.; Arts, M.T.; Morin, J.; Gratton, D.; Martin, C. Hydrodynamic control of the underwater light climate in fluvial Lac Saint-Pierre. Limnol. Oceanogr. 2006, 51, 2632-2645. [CrossRef]

33. Côté, J.-P.; Morin, J. Modifications anthropiques sur 150 ans au lac Saint-Pierre: Une fenêtre sur les transformations de l'écosystème du Saint-Laurent. VertigO 2003, 4, 1-10. [CrossRef]

34. Ouellet, V.; Secretan, Y.; St-Hilaire, A.; Morin, J. Daily averaged 2D water temperature model for the St. Lawrence River. River Res. Appl. 2013, 30, 733-744. [CrossRef]

35. Secretan, Y.F. Contribution à la Résolution des Équations de Navier-Stokes Compressibles par la Méthode des Éléments Finis Adaptatifs. Ph.D. Thesis, ETH, Zurich, Switzerland, 1991.

36. Morin, J.; Champoux, O.; Martin, S.; Turgeon, K. Modélisation Intégrée de la Réponse de L'écosystème dans le Fleuve Saint-Laurent: Rapport Final des Activités Entreprises dans le Cadre du Plan D'étude sur la Régularisation du Lac Ontario et du Fleuve Saint-Laurent; Environnement Canada: Quebec, Canada, 2005.

37. Morin, J.; Mingelbier, M.; Bechara, J.A.; Champoux, O.; Secretan, Y.; Jean, M.; Frenette, J. Emergence of New Explanatory Variables for 2D Habitat Modelling in Large Rivers: The St. Lawrence Experience. Can. Water Resour. J. 2003, 28, 1-24. [CrossRef]

38. McCrimmon, H.R. Carp in Canada. Fish. Resour. Can. Board Bull. 1968, 165, 93-102.

39. Cooper, E.L. Carp in North America; American Fisheries Society: Bethesda, MD, USA, 1987; ISBN 091323544X.

40. Fernandez-Delgado, C. Life history patterns of the common carp, Cyprinus carpio, in the estuary of the Guadalquivir river in south-west Spain. Hydrobiologia 1990, 206, 19-28. [CrossRef]

41. Jorde, K.; Schneider, M.; Peter, A.; Zoellner, F. Fuzzy based models for the evaluation of fish habitat quality and instream flow assessment. In Proceedings of the 3rd International Symposium on Environmental Hydraulics, Tempe, AZ, USA, 5-8 December 2001.

42. Mocq, J.; St-Hilaire, A.; Cunjak, R.A. Assessment of Atlantic salmon (Salmo salar) habitat quality and its uncertainty using a multiple-expert fuzzy model applied to the Romaine River (Canada). Ecol. Modell. 2013, 265, 14-25. [CrossRef]

43. Kerle, F.; Zöllner, F.; Schneider, M.; Böhmer, J.; Kappus, B.; Baptist, M.J. Modelling of long-term fish habitat changes in restored secondary floodplain channels of the river Rhine. In Proceedings of the fourth Ecohydraulics Symposium, Cape Town, SA, South Africa, 3-8 March 2002; p. 15.

44. Zadeh, L.A. Fuzzy sets. Inf. Control. 1965, 8, 338-353. [CrossRef]

45. Bai, Y.; Wang, D. Fundamentals of fuzzy logic control-Fuzzy sets, fuzzy rules and defuzzifications. Adv. Ind. Control. 2006, 17-36. [CrossRef]

46. Barton, B.A. Stress in Fishes: A Diversity of Responses with Particular Reference to Changes in Circulating Corticosteroids. Integr. Comp. Biol. 2002, 42, 517-525. [CrossRef]

47. Vignet, C.; Larcher, T.; Davail, B.; Joassard, L.; Le Menach, K.; Guionnet, T.; Lyphout, L.; Ledevin, M.; Goubeau, M.; Budzinski, H.; et al. Fish Reproduction Is Disrupted upon Lifelong Exposure to Environmental PAHs Fractions Revealing Different Modes of Action. Toxics 2016, 4, 26. [CrossRef]

48. Gaston, K.J.; Butlin, R.K.; Snook, R.R. Local adaptation of reproductive performance during thermal stress. J. Evol. Biol. 2017, 30, 422-429. [CrossRef]

49. Pusey, B.J.; Douglas, M.; Olden, J.D.; Jackson, S.; Allsop, Q.; Kennard, M.J. Connectivity, habitat, and flow regime influence fish assemblage structure: Implications for environmental water management in a perennial river of the wet-dry tropics of northern Australia. Aquat. Conserv. Mar. Freshw. Ecosyst. 2020, 30, 1397-1411. [CrossRef]

50. Carnie, R.; Tonina, D.; Mckean, J.A.; Isaak, D. Habitat connectivity as a metric for aquatic microhabitat quality: Application to Chinook salmon spawning habitat. Ecohydrology 2015, 9, 982-994. [CrossRef]

51. Alexander, L.C.; Autrey, B.; DeMeester, J.; Fritz, K.M.; Goodrich, D.C.; Kepner, W.G.; Lane, C.R.; LeDuc, S.D.; Leibowitz, S.G.; McManus, M.; et al. Connectivity of Streams and Wetlands to Downstream Waters: A Review and Synthesis of the Scientific Evidence. JAWRA J. Am. Water Resour. Assoc. 2013, 54, 287-297. [CrossRef]

52. Duarte, G.; Segurado, P.; Haidvogl, G.; Pont, D.; Ferreira, M.T.; Branco, P. Damn those damn dams: Fluvial longitudinal connectivity impairment for European diadromous fish throughout the 20th century. Sci. Total Environ. 2021, $761,143293$. [CrossRef] 